\title{
MODAL INTELEKTUAL PADA PERUSAHAAN-PERUSAHAAN DI SEKTOR KEUANGAN YANG TERDAFTAR DI BURSA EFEK INDONESIA PERIODE 2010-2014
}

\author{
I.K. Marla Lusda ${ }^{1}$, Hari Wijayanto ${ }^{2}$, Dedi Budiman Hakim ${ }^{3}$ \\ ${ }^{1}$ Mahasiswa Magister Manajemen dan Bisnis FEM IPB \\ ${ }^{2}$ Staf Pengajar FMIPA IPB \\ ${ }^{3}$ Staf Pengajar FEM IPB
}

\begin{abstract}
This study aimed to analyze the company's intellectual capital in the financial sector. The financial sector companies listed in the Indonesian Stock Exchange (BEI) 2010-2014 was used as the sample. The sample selection using purposive sampling method. The data used in this study were secondary data from company annual report obtained from the official website of Indonesia Stock Exchange. Measurement of intellectual capital in this study using a model of Value Added Intellectual Coefficients (VAIC) and measurement of financial performance using ratio analysis with ROA as profitability variable, ATO as productivity variable, and GR as variable growth. The results showed that the overall financial performance of the financial sector in the period of observation were top performers and common performers. Based on the value of company's intellectual capital, the intellectual capital components contributed most was human capital.
\end{abstract}

Keywords: Finance, Intellectual capital, Value added intellectual coefficient, VAIC

\section{PENDAHULUAN}

Keberadaan sektor keuangan memiliki peran penting dalam upaya meningkatkan pertumbuhan ekonomi. Pertumbuhan ekonomi terjadi ketika kapasitas perekonomian mengalami peningkatan dibandingkan dengan periode sebelumnya. Peningkatan kapasitas ekonomi tersebut terjadi apabila terdapat investasi baru ke dalam perekonomian. Dalam hal ini, perusahaan-perusahaan di sektor keuangan berperan penting sebagai media investasi dan penyedia dana bagi pembiayaan perekonomian. Semakin baik keadaan sektor keuangan, maka semakin meningkat penyediaan dana bagi pembiayaan perekonomian sehingga terjadi pertumbuhan ekonomi. Untuk mendukung pertumbuhan ekonomi diperlukan lembaga-lembaga keuangan yang mampu memfasilitasi kebutuhan masyarakat akan aset-aset keuangan. Dalam suatu sistem perekonomian, peran utama lembagalembaga keuangan ialah menjalankan fungsi intermediasi, yakni menyalurkan kembali dana yang telah dihimpun dari masyarakat dalam bentuk pinjaman atau kredit kepada sektor-sektor usaha riil dalam upaya pengembangan usaha masyarakat. Dengan kata lain, melalui fungsi intermediasi yang dijalankannya, sektor keuangan berperan dalam mempercepat pembangunan dan meningkatkan pertumbuhan ekonomi. Studi Kaminsky (1999) menunjukkan keterkaitan antara krisis keuangan dengan krisis ekonomi. Krisis keuangan didahului oleh masalah pada sektor perbankan yang kemudian menyebabkan terjadinya krisis mata uang. Krisis mata uang memperburuk krisis yang terjadi 
pada sektor perbankan. Keduanya membentuk semacam lingkaran setan dalam perekonomian yang hasil akhirnya akan memperparah kesehatan sektor riil dibandingkan krisis yang dipicu oleh permasalahan pada krisis mata uang saja. Lee (2005) juga berpendapat bahwa pertumbuhan ekonomi menyebabkan kenaikan permintaan terhadap produkproduk keuangan sehingga menghasilkan kenaikan aktivitas pasar keuangan dan kredit sehingga perkembangan sektor keuangan menjadi katalisator dalam pertumbuhan ekonomi suatu negara.

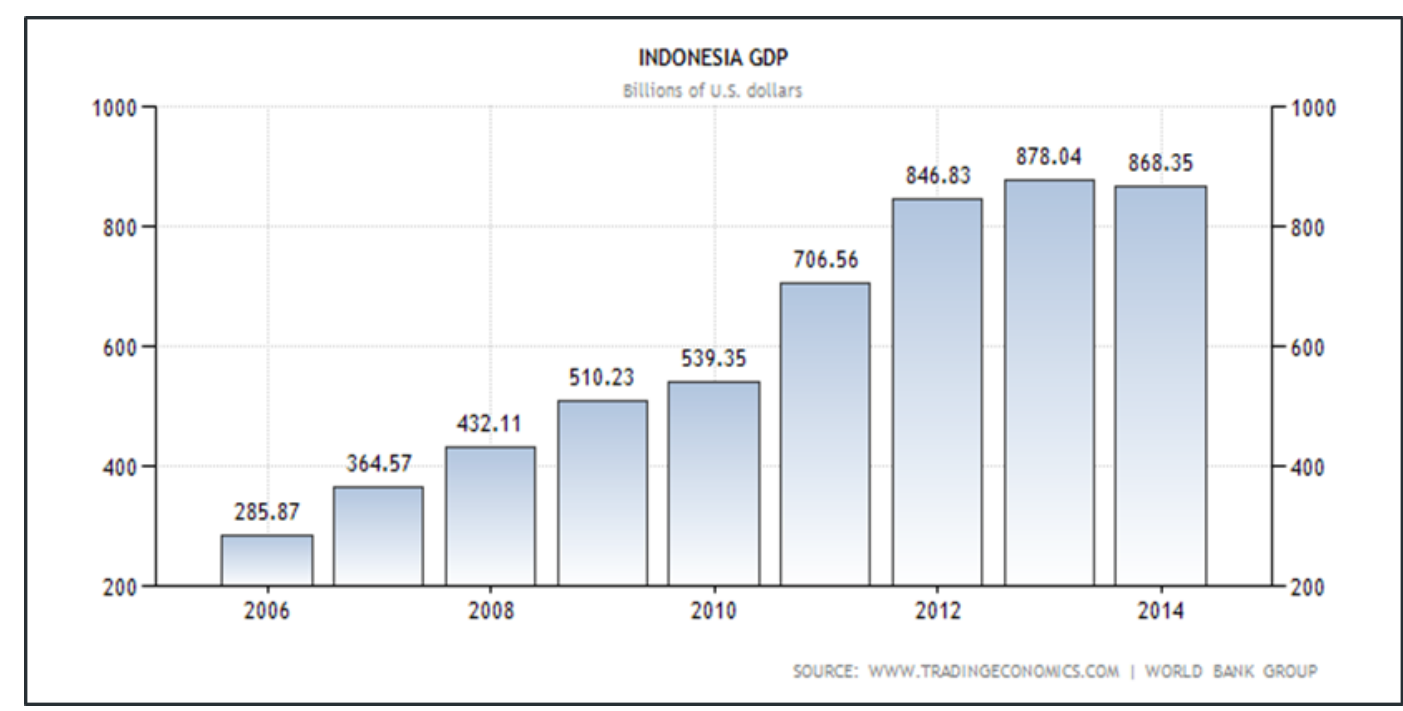

Sumber : www.tradingeconomics.com

Gambar 1 Grafik Pertumbuhan PDB Indonesia (billion of US dollar)

Indonesia sebagai negara berkembang telah mengadopsi serangkaian program dalam struktur keuangan nasional guna meningkatkan performa perekonomian domestik negara. Salah satunya adalah keikutsertaan Indonesia dalam Masyarakat Ekonomi ASEAN (MEA). Dampak dari dibentuknya MEA ini meliputi dampak aliran bebas barang bagi negara-negara ASEAN, dampak arus bebas jasa, dampak arus bebas investasi, dampak arus tenaga kerja terampil, dan dampak arus bebas modal. Sisi positif dari diberlakukannya MEA bagi Indonesia antara lain akan membuka kesempatan yang baik bagi produk lokal dan tenaga kerja lokal Indonesia untuk berkompetisi secara internasional karena hambatan perdagangan akan cenderung berkurang bahkan menjadi tidak ada. Hal tersebut akan berdampak pada peningkatan ekspor yang pada akhirnya akan meningkatkan GDP Indonesia. Data pertumbuhan GDP Indonesia pada tahun 2006 sampai tahun 2014 dapat dilihat pada Gambar 1. Di sisi lain, akan muncul tantangan baru bagi Indonesia berupa competition risk karena banyaknya barang impor yang akan mengalir dalam jumlah besar ke Indonesia yang akan mengancam industri lokal dalam bersaing dengan produk-produk luar negri yang jauh lebih berkualitas. Hal ini yang pada akhirnya akan ditakutkan dapat meningkatkan defisit neraca perdagangan bagi Indonesia sendiri (Santoso, 2008). Oleh karena itu, Indonesia, terutama sektor keuangan, diharapkan dapat lebih peka terhadap fluktuasi yang akan terjadi agar dapat mengantisipasi risiko-risiko yang 
muncul dengan tepat. Indonesia juga perlu meningkatkan kemampuan serta daya saing tenaga kerja dan produk lokal agar dapat aktif berperan dalam MEA. Di samping peningkatan daya saing produk lokal, Indonesia juga harus memaksimalkan pengelolaan Intellectual Capital (IC) yang dimiliki oleh perusahaan-perusahaan pendukung perekonomian Indonesia.

Pengembangan sistem perekonomian global yang dihadapi perusahaan-perusahaan terkait dengan keikutsertaan Indonesia dalam MEA, menyebabkan pengembangan intellectual capital merupakan suatu keharusan agar perusahaan-perusahaan lokal mampu bersaing di kancah internasional tersebut. Agar dapat kompetitif di persaingan industri internasional, perusahaan harus dapat mengembangkan intellectual capital yang meliputi human capital, structural capital, dan customer capital. Human capital meliputi pengetahuan, keahlian, kompetensi dan motivasi yang dimiliki karyawan. Structural capital mencakup budaya perusahaan, software komputer, dan teknologi informasi. Sedangkan customer capital meliputi loyalitas konsumen, pelayanan jasa terhadap konsumen, dan hubungan baik dengan pemasok. Ketiga elemen intellectual capital tersebut berinteraksi secara dinamis, serta terus menerus dan luas sehingga akan menghasilkan nilai bagi perusahaan. Perusahaan yang menjaga aset-aset tersebut dan mengembangkannya, akan menghasilkan keunggulan tersendiri bagi perusahaan tersebut sehingga dapat bertahan dalam persaingan global. Perfoma yang baik bagi suatu perusahaan menyebabkan kepercayaan investor untuk berinvestasi. Hal ini berdampak positif bagi kinerja keuangan perusahaan tersebut. Organisation for Economic Cooperation and
Development (OECD, 1999) menjelaskan IC merupakan nilai ekonomi dari dua kategori aset tak berwujud, yaitu organisational (structural) capital dan human capital. Organisational (structural) capital mengacu pada hal seperti sistem software, jaringan distribusi, dan rantai pasokan. Human capital meliputi sumber daya manusia di dalam organisasi dan sumber daya eksternal yang berkaitan dengan organisasi, seperti konsumen dan supplier.

Menurut Abidin (2000), modal intelektual masih belum dikenal secara luas di Indonesia. Perusahaanperusahaan di Indonesia cenderung menggunakan conventional based dalam membangun bisnisnya sehingga produk yang dihasilkannya masih miskin kandungan teknologi. Di samping itu, perusahaan-perusahaan tersebut belum memberikan perhatian lebih terhadap human capital, structural capital, dan customer capital yang merupakan elemen pembangun modal intelektual perusahaan. Kesimpulan ini dapat diambil karena minimnya informasi tentang modal intelektual di Indonesia. Selanjutnya, Abidin (2000) menyatakan bahwa perusahaan-perusahaan di Indonesia akan dapat bersaing apabila menggunakan keunggulan kompetitif yang diperoleh melalui inovasi-inovasi kreatif yang dihasilkan oleh modal intelektual perusahaan. Hal ini akan mendorong terciptanya produk-produk yang semakin favourable di mata konsumen. Hariyawan (2013) menyatakan bahwa berkembangnya era teknologi ini menyebabkan banyak perusahaan lebih memilih untuk berinvestasi pada aset yang intangible seperti keahlian karyawan, loyalitas customer dan sistem informasi. Aset-aset ini merupakan sumber daya yang unik, sehingga tidak semua perusahaan pesaing mampu untuk menirunya. Hal inilah yang menjadikan 
aset ini menjadi sumber daya bagi perusahaan untuk menciptakan value added tersendiri bagi perusahaan tersebut. Oleh karena itu, aset ini dianggap aset yang strategis karena mampu menghasilkan keunggulan kompetitif berkelanjutan bagi perusahaan.

Pemilihan strategi bersaing merupakan salah satu penentu keberhasilan bisnis. Pemilihan strategi bersaing yang tepat dapat menciptakan kinerja perusahaan yang optimal. Strategi bersaing dapat menghasilkan keunggulan kompetitif dengan menciptakan produk unggulan dengan biaya produksi yang lebih rendah dibanding perusahaan kompetitor atau diferensiasi produk yang memiliki keunikan tertentu yang tidak dapat ditiru oleh perusahaan kompetitor. Dasar penciptaan keunggulan kompetitif tergantung pada penciptaan sumber daya yang dimiliki oleh perusahaan itu sendiri. Perusahaan yang mampu menciptakan keunggulan kompetitif dapat menjaga kelangsungan bisnisnya dalam jangka waktu yang lama. Modal intelektual menentukan daya saing kinerja perusahaan saat ini dan masa depan serta pertumbuhan nilai perusahaan. Hal ini menunjukkan bahwa keunggulan kompetitif yang berasal dari modal intelektual dapat mempengaruhi kinerja perusahaan dan pertumbuhan nilai perusahaan. Kinerja keuangan perusahaan menunjukkan performa perusahaan yang dapat dilihat dalam laporan keuangan sebagai gambaran keadaan perusahaan selama periode tertentu. Kinerja keuangan perusahaan dapat digunakan untuk menentukan ukuran keberhasilan kinerja perusahaan dalam mencapai tujuan perusahaan.

Penelitian mengenai intellectual capital menjadi menarik karena berdasarkan survei global yang dilakukan tahun 1998, ternyata isu-isu mengenai pengungkapan intellectual capital merupakan salah satu dari sepuluh jenis informasi yang dibutuhkan pelaku bisnis. Purnomosidhi (2006) memaparkan hasil survei yang dilakukan oleh Price Waterhouse Coopers (PWC) terhadap jenis-jenis informasi yang dibutuhkan investor. Berdasarkan hasil survei tersebut, terdapat 10 jenis informasi yang dianggap cukup penting yang dikelompokkan menjadi tiga kelompok, yaitu pelanggan, pegawai, dan inovasi. Informasi yang terkait dalam komponen pelanggan antara lain saluran distribusi, brand equity, dan tingkat perputaran pelanggan. Informasi yang terkait dalam komponen pegawai antara lain intelegensi pegawai, tingkat retensi pegawai, dan pendapatan per karyawan. Informasi yang terkait dalam komponen inovasi antara lain pendapatan dari produk baru, tingkat keberhasilan produk baru, pengeluaran untuk penelitian dan pengembangan, serta siklus pengembangan produk. Sebagian besar informasi yang dianggap penting tersebut dapat diklasifikasikan sebagai intellectual capital dan tidak diungkapkan dalam laporan keuangan sehingga menimbulkan kesenjangan informasi.

Berdasarkan sudut pandang investor, salah satu indikator penting untuk menilai prospek perusahaan di masa datang adalah kinerja keuangan perusahaan. Kinerja keuangan perusahaan dapat dilihat dari sejauh mana pertumbuhan profitabilitas dan produktivitas perusahaan tersebut. Indikator ini berperan untuk mengetahui sejauh mana investasi yang akan dilakukan investor di suatu perusahaan mampu memberikan return atau tingkat pengembalian yang sesuai dengan tingkat yang disyaratkan investor. Untuk mengetahui hal tersebut, biasanya digunakan dua rasio, yaitu rasio profitabilitas dan rasio produktivitas. Rasio profitabilitas yang paling sering 
digunakan adalah Return on Asset (ROA). ROA menggambarkan sejauh mana kemampuan aset-aset yang dimiliki perusahaan bisa menghasilkan laba. Rasio produktivitas yang digunakan adalah Asset Turn Over (ATO) dimana rasio ini menunjukkan efisiensi perusahaan dengan menggunakan aktiva untuk menghasilkan pendapatan atau penjualan. Pada umumnya, semakin tinggi rasio ATO suatu perusahaan, maka semakin efisien aktiva perusahaan yang telah digunakan. Gitman (2012) menyatakan bahwa rasio ATO ini merupakan rasio yang paling menarik perhatian manajemen karena menunjukkan apakah operasional suatu perusahaan telah efisien apabila dilihat dari sisi keuangannya. Berdasarkan hal tersebut, ROA dan ATO dianggap sudah cukup mewakili kinerja keuangan suatu perusahaan.

Sangkala (2006) menjelaskan intellectual capital tidak hanya terkait dengan materi intelektual yang terdapat dalam diri karyawan perusahaan seperti pendidikan dan pengalaman. Intellectual capital juga terkait dengan materi atau aset perusahaan yang berbasis pengetahuan, atau hasil dari proses transformasi pengetahuan yang dapat berwujud aset intelektual perusahaan. Aset intelektual tersebut dapat berupa informasi, intellectual property, loyalitas pelanggan, paten, trademark, brand equity, database. Lebih lanjut lagi, Chen et al. (2005) menya-takan bahwa intellectual capital semakin diakui sebagai aset strategis yang penting untuk keunggulan kompetitif perusahaan. Intellectual capital diyakini dapat berperan penting didalam peningkatan profitabilitas perusahaan. Berdasarkan resource based theory, penggunaan sumber daya perusahaan secara efisien dan ekonomis tersebut dapat memperkecil biaya-biaya yang terjadi. Dengan memanfaatkan modal intelektual yang dimilikinya, perusahaan dapat meningkatkan penggunaan sumber daya yang ada secara efisien, sehingga dapat memperkecil biaya dan mengoptimalkan keuntungan. Per-usahaan yang dapat mengelolah dengan baik potensi yang dimiliki oleh karyawannya, akan meningkatkan produktivitas karyawan. Jika produktivitas karyawan meningkat, maka pendapatan dan keuntungan perusahaan juga akan meningkat. Peningkatan pendapatan dan keuntungan perusahaan menunjukkan inerja keuangan perusahaan juga meningkat (Pramelasari, 2010).

Berdasarkan teori stakeholder, perusahaan diharapkan untuk melakukan aktivitas yang dianggap penting oleh stakeholder mereka dan melaporkan kembali aktivitas-aktivitas tersebut kepada stakeholder. Teori ini menyatakan bahwa stakeholder memiliki hak untuk mengetahui informasi tentang bagaimana aktivitas perusahaan. Menurut Deegan (2004), tujuan utama teori ini adalah untuk membantu perusahaan meningkatkan nilai dari dampak aktivitas perusahaan tersebut serta meminimalkan kerugian bagi stakeholder. Stakeholder berkepentingan untuk mempengaruhi perusahaan dalam proses pemanfaatan seluruh potensi yang dimiliki perusahaan karena dengan pengelolaan yang baik, seluruh potensi yang ada tersebut dapat menciptakaan value added yang dapat mendorong kinerja keuangan perusahaan yang juga merupakan orientasi stakeholder.

Berdasarkan konsep Resource Based Theory, jika perusahaan mampu mengelola sumber daya secara efektif maka akan dapat menciptakan keunggulan kompetitif dibanding para pesaing. Sumber daya manusia yang memiliki keterampilan dan kompetensi tinggi merupakan keunggulan kompetitif bagi perusahaan apabila dapat dimanfaatkan dan mengelola potensi 
yang dimiliki karyawan dengan baik, maka hal ini dapat meningkatkan produktivitas karyawan. Dengan adanya peningkatan produktivitas, maka kinerja perusahaan akan meningkat dan dengan adanya pengelolaan sumber daya yang efektif tersebut maka pemakaian sumber daya atau pengeluaran akan lebih efektif dan efisien. Teori ini memandang bahwa perusahaan bersaing berdasarkan sumber daya dan kemampuan yang dimiliki oleh perusahaan. Perbedaan sumber daya dan kemampuan perusahaan dengan perusahaan pesaing akan memberikan keuntungan kompetitif. Kemampuan perusahaan, menunjukkan apa yang dapat dilakukan perusahaan terhadap sumber daya yang dimilikinya.

Berdasarkan kedua teori tersebut (stakeholder theory dan resource based theory), perusahaan yang mempunyai kinerja intellectual capital yang baik cenderung untuk mengungkapkan intellectual capital yang dimiliki oleh perusahaan dengan lebih baik. Dengan kata lain, untuk dapat menarik perhatian pasar, perusahaan harus mampu meningkatkan pengelolaan kinerja intellectual capital. Hal tersebut dapat memperlihatkan bahwa perusahaan mempunyai nilai tambah dibandingkan dengan perusahaan lain, sehingga investor akan menempatkan nilai yang lebih tinggi untuk perusahaan yang memiliki intellectual capital yang besar. Appuhami (2007) juga berpendapat bahwa dalam menilai suatu perusahaan, investor tidak hanya melihat dari harga saham perusahaan saja, melainkan juga melihat adanya modal intelektual yang dimiliki perusahaan. Hal ini menunjukkan pentingnya modal intelektual bagi perusahaan agar investor tertarik untuk berinvestasi.

Peneliti tertarik untuk melakukan penelitian mengenai hubungan intellectual capital dengan kinerja keuangan didasarkan pada argumen kontradiktif yang dihasilkan oleh penelitian yang dilakukan Firer (2003) dan Chen et al. (2005). Perbedaan argumen tersebut akan dikaji ulang oleh peneliti dengan mereplikasi kombinasi penelitian keduanya yang disesuaikan dengan kondisi di Indonesia. Penelitian ini dilakukan untuk mengukur pengaruh intellectual capital terhadap kinerja keuangan perusahaan dan pertumbuhannya. Kombinasi kedua penelitian tersebut dipadukan oleh peneliti dari sisi variabel kinerja keuangan yang diamati. Pada penelitian ini, peneliti menggunakan kombinasi variabel pada penelitian Firer (2003) dan Chen et al (2005), adapun variabel kinerja keuangan yang diamati peneliti antara lain ROA, ATO, dan GR. Namun pada penelitian ini, peneliti menambahkan variabel independen baru, yaitu pertumbuhan rata-rata intellectual capital (ROGIC) untuk mengukur variabel GR. Hal ini dilakukan karena perhitungan pertumbuhan perusahaan dengan perhitungan rasio berbeda.

Berdasarkan gambaran tersebut, maka menjadi penting untuk mengkaji modal intelektual yang ada pada perusahaan sektor keuangan. Tujuan dalam penelitian ini adalah sebagai berikut: 1) mengidenifikasi intellectual capital perusahaan di sektor keuangan, 2) menganalisis pengaruh intellectual capital pada kinerja keuangan perusahaan, dan 3) merumuskan implikasi manajerial dalam peningkatan intellectual capital.

\section{METODE PENELITIAN}

\section{Jenis dan Sumber Data}

Penelitian ini menggunakan data sekunder. Data sekunder yaitu data yang diperoleh secara tidak langsung melalui media perantara atau pihak lain melalui studi dokumentasi dengan mempelajari berbagai tulisan melalui buku, internet, 
dan jurnal yang berhubungan dengan penelitian ini. Data yang digunakan dalam penelitian ini berupa laporan keuangan perusahaan di sektor keuangan yang telah terdaftar di Bursa Efek Indonesia (BEI). Laporan yang digunakan dalam penelitian diperoleh melalui website resmi masing-masing perusahaan, website resmi BI (www.bi.go.id), dan website BEI (www.idx.co.id). Pengamatan dilakukan selama lima tahun berturut-turut, yaitu dari tahun 2010 sampai tahun 2014. Pemilihan periode penelitian ini dengan pertimbangan ketersediaan dan kebaruan data yang ada. Laporan keuangan perusahaan yang digunakan adalah laporan keuangan tahunan periode Desember 2010 sampai Desember 2014.

Pemilihan sektor keuangan dalam penelitian ini karena pada umumnya perusahaan di sektor keuangan memiliki modal intelektual yang dominan dan menjalankan aktivitas operasional dengan modal pengetahuan yang lebih banyak dibandingkan modal fisik. Pemilihan sampel pada penelitian ini menggunakan purposive sampling. Purposive sampling merupakan metode pemilihan sampel dengan menetapkan beberapa kriteria sebagai persyaratan dalam pemilihan sampel. Dalam penelitian ini, peneliti menetapkan beberapa kriteria dalam pemilihan sampel, antara lain:

1. Perusahaan telah menerbitkan laporan keuangan dari tahun 2010-2014 secara lengkap dan berturut-turut.

2. Perusahaan tidak melakukan akuisisi atau merger selama periode pengamatan.

3. Perusahaan mengungkapkan atau menampilkan informasi mengenai beban karyawan dalam laporan tahunannya.

4. Perusahaan tidak memiliki nilai ekuitas yang negatif selama periode pengamatan.
5. Perusahaan tidak mengalami kerugian atau laba negatif selama periode pengamatan.

Berdasarkan kriteria yang ditetapkan tersebut, maka didapat jumlah emiten yang memenuhi kriteria dan bisa dijadikan sampel dalam penelitian ini dapat dilihat pada Tabel 1.

Tabel 1 Daftar emiten sektor keuangan

\begin{tabular}{lrr}
\hline Sub Sektor & $\begin{array}{l}\text { Jumlah } \\
\text { emiten }\end{array}$ & $\begin{array}{l}\text { Jumlah } \\
\text { emiten yang } \\
\text { memenuhi } \\
\text { kriteria }\end{array}$ \\
\hline Perbankan & 41 & 30 \\
Financing & 15 & 11 \\
Perusahaan & 10 & 10 \\
Efek & 11 & 10 \\
Asuransi & 1 & 0 \\
Lainnya & 78 & 61 \\
Total Sampel & &
\end{tabular}

Sumber: Data diolah

Penelitian ini menggunakan metode pendekatan kuantitatif berupa statistik deskriptif yang melibatkan variabel independen dan variabel dependen dari data sekunder. Statistik deskriptif memberikan gambaran atau deskripsi suatu data secara statistik. Data tersebut merupakan data olahan dari perhitungan rasio keuangan perusahaan, serta perhitungan pengukuran intellectual capital dengan menggunakan metode VAIC. Analisis statistik deskriptif ini dapat dilihat dari nilai ratarata (mean), standar deviasi, maksimum, minimum (Ghozali, 2011). Selanjutnya, untuk menghitung variabel independen (intellectual capital), digunakan metode Value Added Intellectual Coefficient (VAIC). VAIC merupakan prosedur analisis yang didesain untuk memungkinkan manajemen, pemegang saham, dan stakeholder untuk memonitor dan mengevaluasi secara efisiensi dari nilai tambah yang dihasilkan oleh penggunaan sumber daya 
perusahaan. Untuk mengukur variabel dependen berupa kinerja keuangan perusahaan, dilakukan dengan menggunakan rumusan rasio keuangan.

Adapun variabel yang digunakan dalam penelitian ini meliputi variabel independen dan variabel dependen. Variabel independen yang digunakan adalah intellectual capital. Intellectual capital yang dimaksudkan dalam penelitian ini merupakan kombinasi dari value added yang diciptakan oleh physycal capital (VACA), human capital (VAHU), dan structural capital (STVA) dimana ketiga nilai ini nantinya akan diukur dengan Value Added Intellectual Coefficient (VAIC).

\section{Spesifikasi Variabel}

Modal intelektual atau intellectual capital yang merupakan intangible assets perusahaan menjadi aset yang sangat bernilai. Seiring semakin bernilainya modal intelektual sebagai aset perusahaan, memberikan tantangan tersendiri bagi para akuntan untuk dapat mengidentifikasikan, mengukur dan mengungkapkannya kedalam laporan keuangan perusahaan. Intellectual capital adalah sesuatu yang tidak mudah untuk diukur, karena itu, Pulic (1998), tidak mengukur secara langsung intellectual capital perusahaan, melainkan mengajukan suatu ukuran untuk menilai efisiensi dari nilai tambah sebagai hasil dari kemampuan intelektual perusahaan, yaitu VAIC. Komponen utama VAIC dapat dilihat dari sumber daya perusahaan, yaitu physical capital (VACA), human capital (VAHU), dan structural capital (STVA). Menurut Pulic, tujuan utama dalam ekonomi yang berbasis pengetahuan adalah untuk menciptakan nilai tambah atau value added, sementara untuk dapat menciptakan value added tersebut dibutuhkan ukuran yang tepat tentang physical capital (yaitu dana-dana keuangan) dan intellectual potential yang direpresentasikan oleh karyawan dengan segala potensi dan kemampuan yang melekat pada mereka. Lebih lanjut, Pulic menyatakan bahwa VAIC menunjukkan bagaimana kedua sumber daya tersebut telah secara efisien dimanfaatkan oleh perusahaan. Karena itulah kemudian muncul konsep value added intellectual coefficient (VAIC) yang menjadi solusi untuk mengukur dan melaporkan IC dengan mengacu pada informasi keuangan perusahaan. VAIC merupakan metode pengukuran berbasis keuangan yang digunakan untuk mengukur nilai modal intelektual. Metode VAIC dikembangkan oleh Pulic (1998), didesain untuk menyajikan informasi tentang value creation efficiency dari aset berwujud (tangible asset) dan aset tidak berwujud (intangible assets) yang dimiliki perusahaan. Model ini dimulai dengan kemampuan perusahaan untuk menciptakan value added (VA). Value added adalah indikator paling objektif untuk menilai keberhasilan bisnis dan menunjukkan kemampuan perusahaan dalam penciptaan nilai (value creation).

Dalam penelitian ini, pengukuran modal intelektual diukur dengan menggunakan model VAIC. Model ini merupakan pendekatan yang tepat untuk mengukur nilai tambah yang didapatkan perusahaan dari hasil pengolahan sumber daya yang optimal yang dilaporkan oleh manajerial perusahaan kepada stakeholder dalam bentuk laporan tahunan perusahaan. Adapun variabel yang digunakan dalam penelitian ini meliputi variabel independen dan variabel dependen. Variabel independen yang digunakan adalah intellectual capital. Intellectual capital yang dimaksudkan dalam penelitian ini merupakan kombinasi dari value added yang diciptakan oleh physycal capital (VACA), human capital (VAHU), dan 
structural capital (STVA) dimana ketiga nilai ini nantinya akan diukur dengan Value Added Intellectual Coefficient (VAIC). Formulasi dan perhitungan VAIC terdiri dari lima tahapan, yaitu:

1. Menghitung value added (VA) VA dihitung sebagai selisih antara output dan input. VA juga dapat dihitung dari akun-akun perusahaan yang ada dalam laporan keuangan perusahaan.

$$
\mathbf{V A}=\mathbf{O U T}-\mathbf{I N}
$$

Dimana:

$$
\begin{aligned}
\text { OUT (output) : } & \text { pendapatan } \\
& \text { operasional dan laba } \\
& \text { operasional. }
\end{aligned}
$$

IN (input) $\quad$ : biaya operasional
selain beban
karyawan (beban
operasional,
depresiasi, dan
amortisasi)

2. Menghitung value added capital employed (VACA)

VACA adalah indikator untuk VA yang diciptakan oleh satu unit dari physical capital. Nilai ini menunjukkan kontribusi yang dibuat oleh setiap unit dari CE terhadap value added organisasi.

\section{$\mathrm{VACA}=\mathrm{VA} / \mathrm{CE}$}

Dimana:

CE : dana yang tersedia pada perusahaan, seperti ekuitas dan laba bersih

$$
\text { (total aset-total kewajiban) }
$$

3. Menghitung value added human capital (VAHU)

VAHU menunjukkan berapa banyak VA dapat dihasilkan dengan dana yang dikeluarkan untuk tenaga kerja. Nilai ini menunjukkan kontribusi yang dibuat oleh setiap rupiah yang diinvestasikan dalam $\mathrm{HC}$ terhadap value added perusahaan.

$$
\text { VAHU }=\text { VA } / \text { HC }
$$

Dimana:

HC : beban karyawan

4. Menghitung structural capital value added (STVA)

Nilai ini mengukur jumlah structural capital SC yang dibutuhkan untuk menghasilkan satu rupiah dari VA dan merupakan indikasi bagaimana keberhasilan SC dalam penciptaan nilai.

$$
\text { STVA }=\text { SC } / \text { VA }
$$

Dimana:

$\mathrm{SC}: \mathrm{VA}-\mathrm{HC}$

5. Menghitung value added intellectual coefficient (VAIC)

VAIC mengindikasikan kemampuan intelektual perusahaan yang dibangun dari komponen VACA, VAHU, dan STVA.

$$
\text { VAIC = VACA + VAHU + STVA }
$$

Variabel dependen yang digunakan dalam penelitian ini adalah kinerja keuangan perusahaan sektor keuangan. Dengan mengacu pada penelitian Chen et al (2005) dan Firer (2003), variabel kinerja keuangan menggunakan proksi profitabilitas dan produktivitas. Proksi profitabilitas perusahaan dapat dilihat dari variabel ROA. Untuk proksi produktivitas perusahaan dapat dilihat dari variabel ATO (asset turn over) dan GR (growth rate). Analisis rasio dilakukan dengan menghitung variabel dependen dalam penelitian untuk melihat kinerja keuangan perusahaan. Pada penelitian ini dilakukan analisis rasio dengan ROA, ATO, dan GR. Return on Asset (ROA) 
atau rasio laba atas aset yang digunakan untuk mengetahui sampai seberapa jauh aset yang digunakan dapat menghasilkan laba bersih. ROA merefleksikan keuntungan bisnis dan efisiensi perusahaan dalam memanfaatkan seluruh sumber daya (asset) yang dimiliki perusahaan (Chen et al., 2005). ATO adalah rasio dari total pendapatan terhadap nilai buku dari total aset (Firer, 2003). ATO menunjukkan apakah operasional suatu perusahaan telah efisien atau belum jika dilihat dari sisi keuangannya. GR mengukur perubahan pendapatan perusahaan. Peningkatan pendapatan biasanya merupakan sinyal bagi peusahaan untuk dapat tumbuh dan berkembang (Chen et al., 2005).

- Return on Asset (ROA)

Formula untuk memperoleh ROA, yaitu:

\section{ROA = Laba Bersih /Total Aset}

- Assets Turn Over (ATO)

Formula untuk memperoleh ATO, yaitu:

\section{ATO $=$ Total Pendapatan $/$ Total Aset}

- Growth Rate (GR)

Formula untuk memperoleh GR, yaitu:

$$
\mathbf{G R}=\frac{\text { Total Pendapatan tahun ke-t }}{\text { Total Pendapatan tahun ke-t-1 }}-\mathbf{1}
$$

\section{HASIL DAN PEMBAHASAN}

Sektor keuangan memegang peranan yang sangat signifikan dalam memicu pertumbuhan ekonomi suatu negara karena sektor keuangan mampu memobilisasi tabungan. Sektor keuangan menyediakan berbagai instrumen keuangan dengan kualitas tinggi dan resiko rendah kepada para peminjam. Hal ini akan menambah investasi dan akhirnya mempercepat pertumbuhan ekonomi. Artinya kemajuan sistem keuangan akan menjadi katalisator dalam pertumbuhan ekonomi (Kularatne, 2002). Sekuritas atau surat berharga merupakan salah satu instrumen keuangan yang diperjualbelikan dalam sektor keuangan. Kegiatan perdagangan instrumen keuangan tersebut dilakukan di bursa. Bursa merupakan suatu tempat untuk melakukan perdagangan tanpa harus menyediakan tempat fisik tersebut. Di Indonesia terdapat dua bursa, yaitu Bursa Efek Jakarta dan Bursa Efek Surabaya yang kemudian bergabung menjadi Bursa Efek Indonesia. Demi efektivitas operasional dan transaksi, pemerintah memutuskan untuk menggabung Bursa Efek Jakarta sebagai pasar saham dengan Bursa Efek Surabaya sebagai pasar obligasi dan derivatif. Bursa hasil penggabungan ini mulai beroperasi pada 1 Desember 2007.

Sektor keuangan yang terdapat di Bursa Efek Indonesia terdiri dari lima sub sektor, antara lain sub sektor perbankan, sub sektor lembaga pembiayaan, sub sektor perusahaan efek, dan sub sektor asuransi serta sub sektor pendanaan lainnya. Sebaran emiten pada masing-masing sub sektor keuangan BEI periode 2010-2014 terdapat pada Gambar 2. Dari Gambar 2, diketahui lebih dari $50 \%$ sektor keuangan didominasi oleh perbankan dan sisanya diisi oleh sektor lain seperti lembaga pembiayaan, perusahaan efek dan perusahaan asuransi masing-masing sebesar 19\%, 13\%, dan 14\%. Berdasarkan sebaran tersebut, sektor keuangan didominasi oleh sub sektor perbankan, dimana terdapat 41 bank yang terdaftar di BEI. Sub sektor lain yang terdaftar di sektor keuangan BEI selain perbankan antara lain sub sektor lembaga pembiayaan yang memiliki 15 emiten yang terdaftar, sub sektor perusahaan efek yang memiliki 10 emiten yang terdaftar, dan sub sektor asuransi yang memiliki 11 emiten yang terdaftar. Sub sektor lain yang terdaftar 
di sektor keuangan adalah emiten PT. Bumi Teknokultura Unggul Tbk yang merupakan perusahaan penghasil bahan baku.

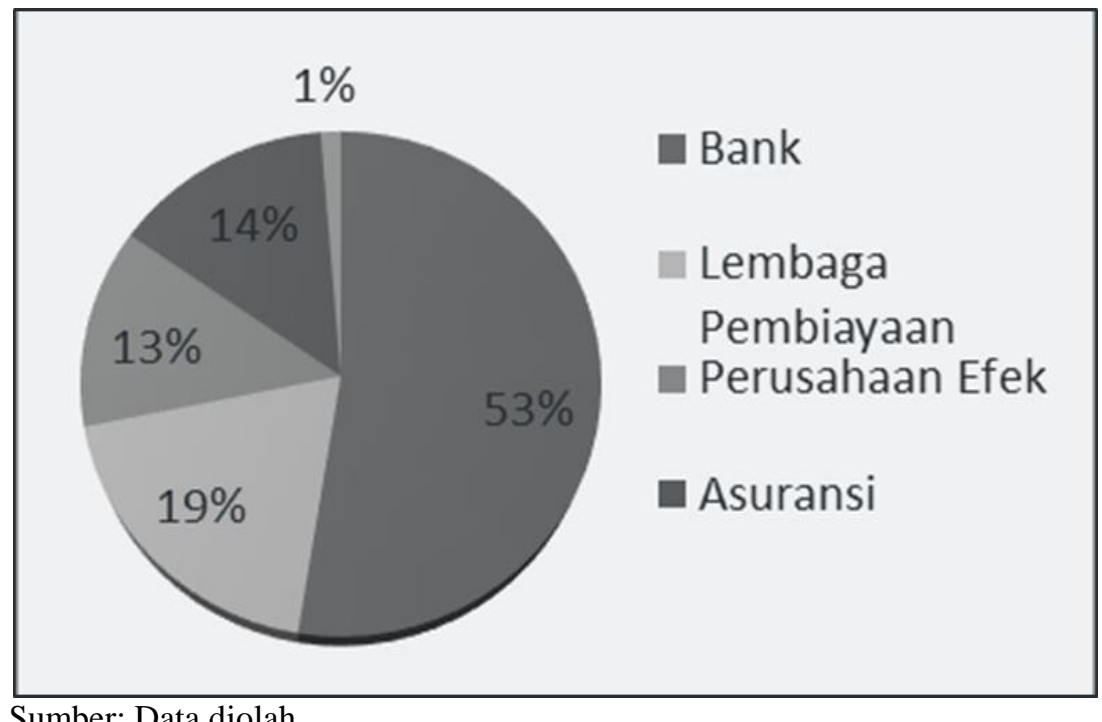

Sumber: Data diolah

Gambar 2 Persentase emiten sektor keuangan BEI 2010-2014

Sub sektor yang mendominasi sektor keuangan adalah sub sektor perbankan. Perbankan merupakan salah satu sektor yang diharapkan berperan aktif dalam menunjang kegiatan pembangunan nasional. Peran itu diwujudkan dalam fungsi utamanya sebagai lembaga intermediasi atau institusi perantara antara debitor dan kreditor yang menjembatani kebutuhan modal antara pemilik dana dan peminjam dana. Dengan demikian, pelaku ekonomi yang membutuhkan dana untuk menunjang kegiatannya dapat terpenuhi dan kemudian roda perekonomian bergerak. Fungsi lain dari bank yang menunjukkan pentingnya keberadaan perbankan dalam per-ekonomian antara lain bank sebagai pencipta uang, bank mendukung kelancaran mekanisme pembayaran, bank sebagai penghimpun dana simpananan masyarakat, bank mendukung kelancaran transaksi internasional, dan bank sebagai penyimpan barang-barang berharga.

Sektor jasa keuangan yang terdiri dari perbankan, lembaga pembiayaan, perusahaan efek, dan perusahaan asuransi mempunyai peranan yang penting dan strategis bagi perekonomian dan masyarakat pada umumnya. Sektor jasa keuangan tidak saja memberikan kontribusi langsung terhadap pembentukkan produk domestik bruto (PDB), namun juga ikut memberikan kontribusi bagi perekonomian dan masyarakat melalui proses intermediasi keuangan (financial intermediation) dimana fungsinya sebagai perantara adalah memobilisasi dan mengalokasikan dana dari surplus unit ke defisit unit dalam perekonomian sehingga ikut menggerakkan dan mendukung perekonomian nasional. Melalui proses intermediasi keuangan tersebut, sektor jasa keuangan dapat mempengaruhi besarnya investasi dan modal kerja yang tersedia di dunia usaha serta tingkat konsumsi masyarakat. Hal tersebut diperlukan untuk mendorong pertumbuhan ekonomi yang berkelanjutan dan stabil. Hasil perhitungan statistik komponen intellectual capital dapat dilihat pada Tabel 2. 
Tabel 2. Hasil perhitungan statistik komponen intellectual capital

\begin{tabular}{lrrrrr}
\hline \multicolumn{1}{c}{ Variabel } & $\mathrm{N}$ & Minimum & Maximum & Mean & Std. Deviation \\
\hline VACA_Bank & 150 & $-3,94$ & 01,43 &, 3823 &, 46277 \\
VAHU_Bank & 150 & $-3,29$ & 22,38 & 34.142 & 327.541 \\
STVA_Bank & 150 & $-22,27$ & 09,12 &, 4878 & 222.541 \\
VAIC_Bank & 150 & $-22,22$ & 1,004861111 & 42.841 & 429.818 \\
VACA_Financing & 55 &, 01 & 01.23 &, 4489 &, 29454 \\
VAHU_Financing & 55 &, 13 & 16,36 & 42.240 & 363.555 \\
STVA_Financing & 55 & $-6,48$ &, 94 &, 5022 &, 98727 \\
VAIC_Financing & 55 & $-6,34$ & 0,754166667 & 51,749 & 406.445 \\
VACA_Effect & 50 & $-1,32$ &, 93 &, 1500 &, 40363 \\
VAHU_Effect & 50 & $-26,01$ & 20,24 & 26.342 & 695.860 \\
STVA_Effect & 50 & $-47,12$ & 0,190972222 &,- 2022 & 684.271 \\
VAIC_Effect & 50 & $-47,09$ & 21,46 & 25.818 & $1.018,817$ \\
VACA_Insurance & 50 &,- 12 &, 79 &, 3728 & .17876 \\
VAHU_Insurance & 50 &,- 45 & 32.23 .00 & 54.860 & 645.687 \\
STVA_Insurance & 50 & -.47 & 03,54 &, 6986 &, 65289 \\
VAIC_Insurance & 50 & .64 & 33.48 .00 & 65.568 & 654.943 \\
\hline Sib_: & & & & &
\end{tabular}

Sumber : data diolah

Berdasarkan hasil stastistik dengan jumlah pengamatan pada sampel $(\mathrm{N})$ sebesar 150 sampel untuk perbankan, 55 sampel untuk perusahaan lembaga pembiayaan (financing), 50 sampel untuk perusahaan efek, dan 50 sampel untuk perusahaan asuransi. Sehingga total keseluruhan data adalah 305 data dari 61 perusahaan yang diamati. Pengamatan pada laporan keuangan perusahaan-perusahaan tersebut dilakukan selama 5 tahun pengamatan yaitu dari tahun 2010 hingga 2014. Dari Tabel 2, efisiensi modal fisik (VACA) memiliki nilai rata-rata sebesar 0,3823 pada sektor perbankan, 0,4489 pada sektor financing, 0,15 pada sektor perusahaan efek, dan 0,3728 pada sektor asuransi. Artinya, setiap penggunaan satu rupiah modal fisik rata-rata yang dihasilkan, akan menghasilkan 0,3823 rupiah value added bagi sektor perbankan, 0,4489 rupiah bagi sektor financing, 0,15 rupiah bagi sektor perusahaan efek, dan 0,3728 rupiah bagi sektor asuransi.

Nilai rata-rata efisiensi pada human capital (VAHU) yang dihasilkan pada sektor perbankan adalah 3,4142; pada sektor financing 4,2240 pada sektor perusahaan efek 2,6342; dan pada perusahaan asuransi 5,486. Artinya, ratarata nilai tambah yang dihasilkan sektor perbankan adalah sebesar 3,4142 pada setiap satu rupiah pengeluaran yang diinvestasikan untuk karyawan atau tenaga kerja. Rata-rata nilai tambah yang dihasilkan sektor financing adalah sebesar 4,224 pada setiap satu rupiah pengeluaran yang diinvestasikan untuk karyawan atau tenaga kerja. Rata-rata nilai tambah yang dihasilkan sektor perusahaan efek adalah sebesar 2,6342 pada setiap satu rupiah pengeluaran yang diinvestasikan untuk karyawan atau tenaga kerja. Rata-rata nilai tambah yang dihasilkan sektor asuransi adalah sebesar 5,486 pada setiap satu rupiah 
pengeluaran yang diinvestasikan untuk karyawan atau tenaga kerja.

Nilai rata-rata efisiensi pada structural capital (STVA) yang dihasilkan pada sektor perbankan adalah 0.4878, pada sektor financing 0.5022 , pada sektor perusahaan efek -0.2022 , dan pada sektor asuransi 0.6986. Nilai ratarata structural capital menunjukkan seberapa besar modal struktural memberikan nilai tambah bagi perusahaan itu sendiri. Artinya bahwa structural capital memberikan 0.4878 kali nilai tambah bagi sektor perbankan, 0.5022 kali nilai tambah bagi sektor financing, -0.2022 bagi sektor perusahaan efek, dan 0.6986 kali bagi sektor asuransi.

Pada sektor perbankan, nilai indikator VACA tertinggi terdapat pada Bank Tabungan Negara Tbk (2011) dengan nilai sebesar 1.43 dengan standar deviasi sebesar 0.46277 , sedangkan nilai indikator VACA terendah terdapat pada Bank Tabungan Negara Tbk (2013) dengan nilai sebesar -3.94. Nilai VACA terbesar, yaitu 1.43 menunjukkan bahwa aset yang dimiliki BTN mampu memberikan nilai tambah sebesar 1.43 kali lipat dari nilai aset tersebut. BTN mengalami penurunan VACA pada tahun 2013 dikarenakan nilai total kewajiban BTN lebih besar daripada nilai total asset yang dimilikinya. Pada sektor financing atau lembaga pembiayaan, nilai indikator VACA tertinggi terdapat pada perusahaan Adira Dinamika Multi Finance Tbk (2010) dengan nilai sebesar 1.23 dengan standar devisiasi 0.29454, sedangkan nilai VACA terendah adalah 0.01 terdapat pada perusahaan Tifa Finance Tbk (2014). Nilai VACA terbesar yaitu 1.23 menunjukkan bahwa aset yang dimiliki perusahaan Adira Dinamika Multi Finance mampu memberikan nilai tambah sebesar 1.23 kali dari nilai aset perusahaan tersebut. Pada sektor perusahaan efek, nilai indikator VACA tertinggi terdapat pada perusahaan Onix Capital Tbk (2014) dengan nilai sebesar 0.93 dengan standar devisiasi 0.40363 , sedangkan nilai VACA terendah adalah 1.32 terdapat pada perusahaan Majapahit Securities Tbk (2011). Nilai VACA terbesar yaitu 0.93 menunjukkan bahwa aset yang dimiliki perusahaan Onix Capital Tbk mampu memberikan nilai tambah sebesar 0.93 kali dari nilai aset perusahaan tersebut. Pada sektor perusahaan asuransi, nilai indikator VACA tertinggi terdapat pada perusahaan Asuransi Bina Dana Arta Tbk (2010) dengan nilai sebesar 0.79 dengan standar devisiasi 0.17879, sedangkan nilai VACA terendah adalah 0.12 terdapat pada perusahaan Asuransi Bintang Tbk (2010). Nilai VACA terbesar yaitu 0.79 menunjukkan bahwa aset yang dimiliki perusahaan Asuransi Bina Dana Arta Tbk mampu memberikan nilai tambah sebesar 0.79 kali dari nilai aset perusahaan tersebut.

Pada sektor perbankan, nilai indikator VAHU tertinggi terdapat pada Bank Himpunan Saudara 1906 Tbk (2013) dengan nilai sebesar 22.38 dengan standar deviasi sebesar 3.27541 sedangkan nilai indikator VAHU terendah terdapat pada perusahaan Bank Pundi Indonesia Tbk (2010) dengan nilai sebesar -3.29. Nilai VAHU terbesar, yaitu 22.38 menunjukkan bahwa setiap 1 rupiah pembayaran gaji karyawan pada Bank Himpunan Saudara 1906 Tbk, mampu menciptakan nilai tambah sebesar 22.38 kali lipat bagi perusahaan itu sendiri. Pada sektor financing atau lembaga pembiayaan, nilai indikator VAHU tertinggi terdapat pada perusahaan Clifan Finance Indonesia Tbk (2012) dengan nilai sebesar 16.36 dengan standar devisiasi 3.63555 sedangkan nilai indikator VAHU terendah pada perusahaan Tifa Finance Tbk (2014) dengan nilai sebesar 0.13. 
Nilai VAHU terbesar, yaitu 16.36 menunjukkan bahwa setiap satu rupiah pembayaran gaji karyawan pada perusahaan Clifan Finance Tbk mampu menciptakan nilai tambah sebesar 16.36 kali lipat bagi perusahaan itu sendiri. Pada sektor perusahaan efek, nilai indikator VAHU tertinggi terdapat pada perusahaan Minna Padi Investama Tbk (2010) dengan nilai sebesar 20.24 dengan standar devisiasi 6.9586 sedangkan nilai indikator VAHU terendah pada perusahaan Majapahit Securities Tbk (2011) dengan nilai sebesar -26.01. Nilai VAHU terbesar, yaitu 20.24 menunjukkan bahwa setiap 1 rupiah pembayaran gaji karyawan pada perusahaan Minna Padi Investama mampu menciptakan nilai tambah sebesar 20.24 kali lipat bagi perusahaan itu sendiri. Pada sektor asuransi, nilai indikator VAHU tertinggi terdapat pada perusahaan Panin Insurance Tbk (2010) dengan nilai sebesar 32.23 dengan standar devisiasi 6.45687 sedangkan nilai indikator VAHU terendah pada perusahaan Asuransi Bintang Tbk (2010) dengan nilai sebesar -0.45 . Nilai VAHU terbesar, yaitu 32.23 menunjukkan bahwa setiap satu rupiah pembayaran gaji karyawan pada perusahaan Panin Insurance mampu menciptakan nilai tambah sebesar 32.23 kali lipat bagi perusahaan itu sendiri.

Pada sektor perbankan, nilai indikator STVA tertinggi terdapat pada Bank MNC Internasional Tbk (2011) dengan nilai sebesar 9.12 dengan standar deviasi sebesar 2.22541. sedangkan nilai indikator STVA terendah terdapat pada Bank Kesawan Tbk (2012) dengan nilai sebesar -22.27. Nilai STVA terbesar, yaitu 9.12 pada Bank MNC Internasional menunjukkan bahwa structural capital memberikan 9.12 kali nilai tambah bagi perusahaan itu sendiri. Pada sektor financing atau lembaga pembiayaan, nilai indikator STVA tertinggi terdapat pada perusahaan Clifan Finance Indonesia Tbk (2012) dengan nilai sebesar 0.94 dengan standar deviasi sebesar 0.98727. sedangkan nilai indikator STVA terendah terdapat pada perusahaan Tifa Finance Tbk (2014) dengan nilai sebesar -6.48. Nilai STVA terbesar, yaitu 0.94 pada perusahaan Clifan Finance Indonesia menunjukkan bahwa structural capital memberikan 0.94 kali nilai tambah bagi perusahaan itu sendiri. Pada sektor perusahaan efek, nilai indikator STVA tertinggi terdapat pada perusahaan Onix Capital Tbk (2010) dengan nilai sebesar 3.95 dengan standar deviasi sebesar 6.84271. sedangkan nilai indikator STVA terendah terdapat pada perusahaan Trimegah Securities Tbk (2012) dengan nilai sebesar -47.12. Nilai STVA terbesar, yaitu 3.95 pada perusahaan Onix Capital menunjukkan bahwa structural capital memberikan 3.95 kali nilai tambah bagi perusahaan itu sendiri. Pada sektor perusahaan asuransi, nilai indikator STVA tertinggi terdapat pada perusahaan Asuransi Bintang Tbk (2011) dengan nilai sebesar 3.54 dengan standar deviasi sebesar 0.65289. sedangkan nilai indikator STVA terendah terdapat pada perusahaan Asuransi Jaya Tania Tbk (2013) dengan nilai sebesar -0.47 . Nilai STVA terbesar, yaitu 3.54 pada perusahaan Asuransi Bintang menunjukkan bahwa structural capital memberikan 3.54 kali nilai tambah bagi perusahaan itu sendiri.

Data penelitian pada Tabel 2 juga menunjukkan nilai rata-rata VAIC perusahaan-perusahaan sektor keuangan. Nilai rata-rata VAIC pada perusahaan perbankan adalah sebesar 4.2841 dengan standar deviasi sebesar 4.29818. Gambar 3 menunjukkan persentase komposisi setiap elemen intellectual capital yang berperan dalam sub sektor perbankan dimana VAHU mendominasi VAIC sebesar $80 \%$. Hal ini 
menunjukkan bahwa peranan sumber daya manusia sangat besar dalam penciptaan nilai tambah pada perusahaan perbankan.

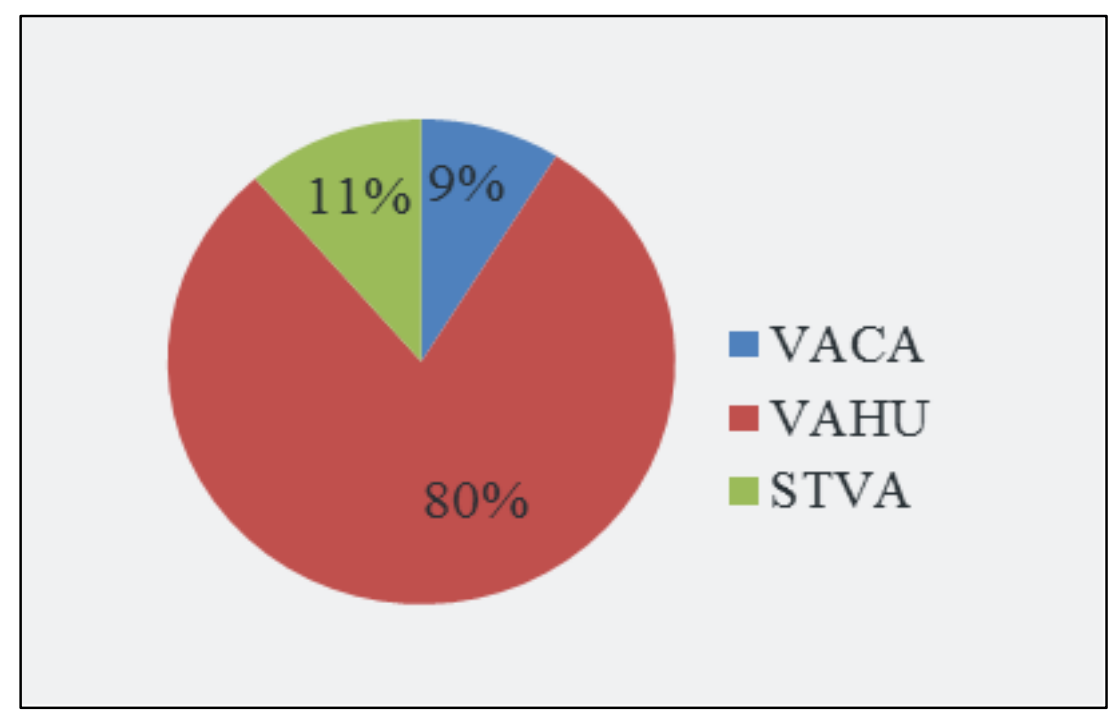

Sumber: Data diolah

Gambar 3 Komposisi komponen intel-lectual capital sub sektor perbankan

Nilai rata-rata VAIC pada perusahaan financing adalah sebesar 5.1749 dengan standar deviasi sebesar 4.06445. Gambar 4 menunjukkan persentase komposisi setiap elemen intellectual capital yang berperan dalam sub sektor lembaga pembiayaan dimana VAHU mendominasi VAIC sebesar 81\%. Hal ini menunjukkan bahwa peranan sumber daya manusia sangat besar dalam penciptaan nilai tambah pada perusahaan lembaga pembiayaan.

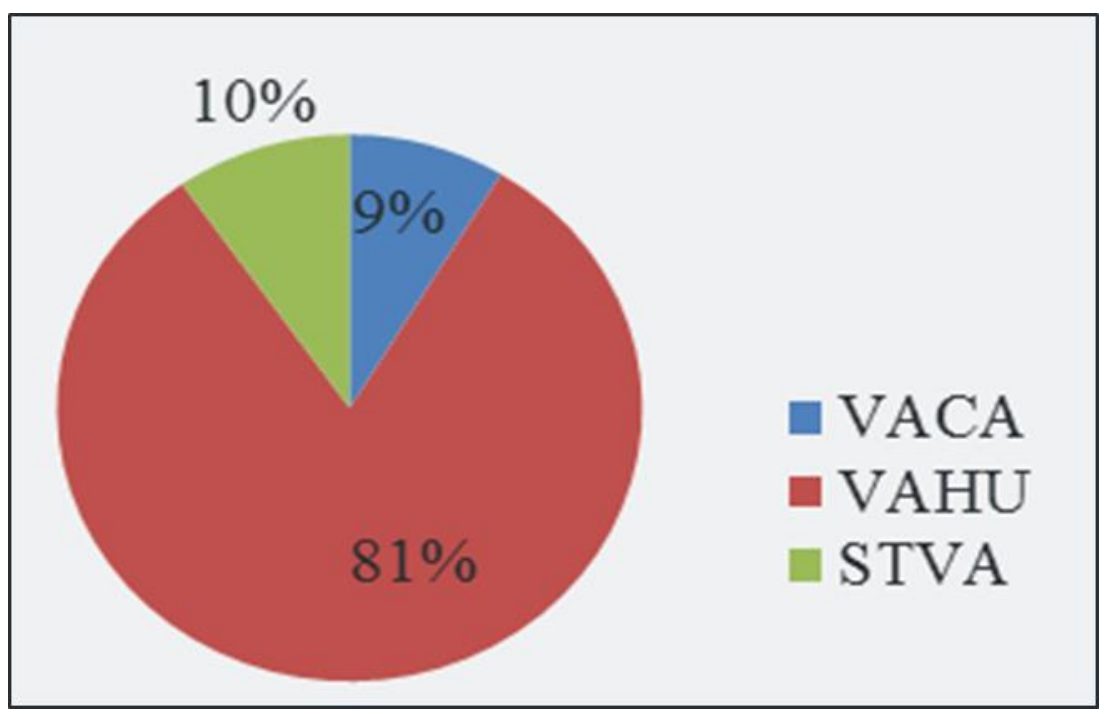

Sumber: Data diolah

Gambar 4 Komposisi komponen intel-lectual capital sub sektor financing

Nilai rata-rata VAIC pada perusahaan efek adalah sebesar 2.5818 dengan standar deviasi sebesar
10.18817. Gambar 5 menunjukkan persentase komposisi setiap elemen intellectual capital yang berperan dalam 
sub sektor perusahaan efek dimana VAHU mendominasi VAIC sebesar $88 \%$. Hal ini menunjukkan bahwa peranan sumber daya manusia sangat besar dalam penciptaan nilai tambah pada perusahaan perusahaan efek.

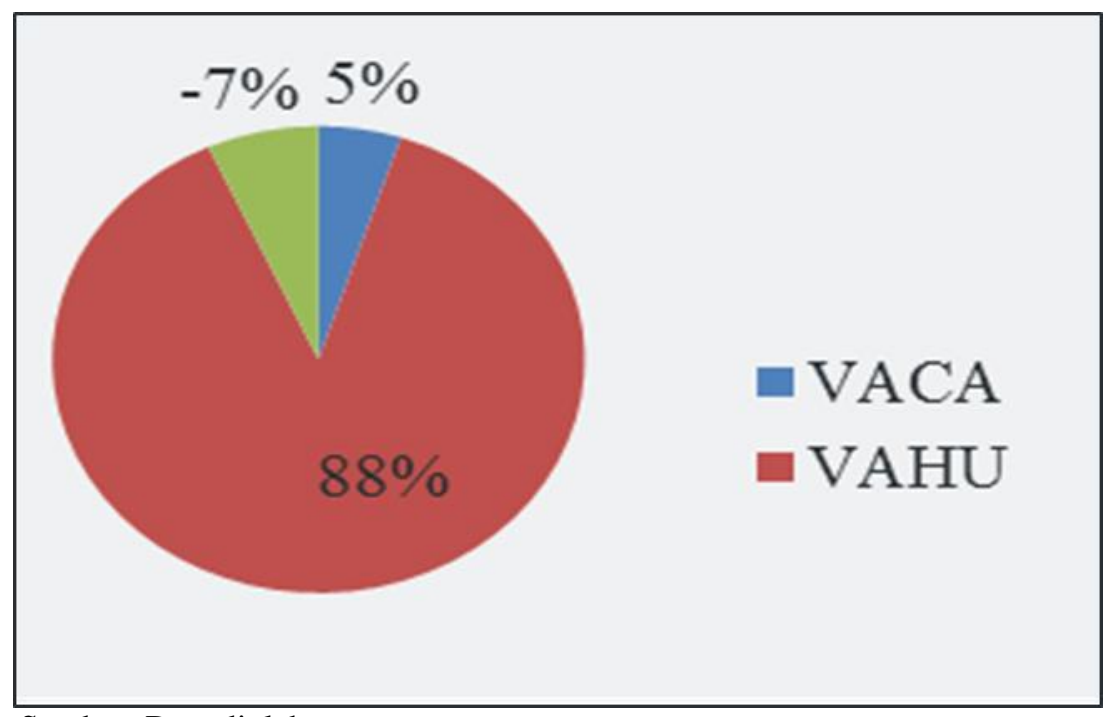

Sumber: Data diolah

Gambar 5 Komposisi komponen intellectual capital sub sektor perusahaan efek

Nilai rata-rata VAIC pada perusahaan asuransi adalah sebesar 6.5568 dengan standar deviasi sebesar 6.54943. Gambar 6 menunjukkan persentase komposisi setiap elemen intellectual capital yang berperan dalam sub sektor perusahaan asuransi dimana VAHU mendominasi VAIC sebesar $84 \%$. Hal ini menunjukkan bahwa peranan sumber daya manusia sangat besar dalam penciptaan nilai tambah pada perusahaan perusahaan asuransi.

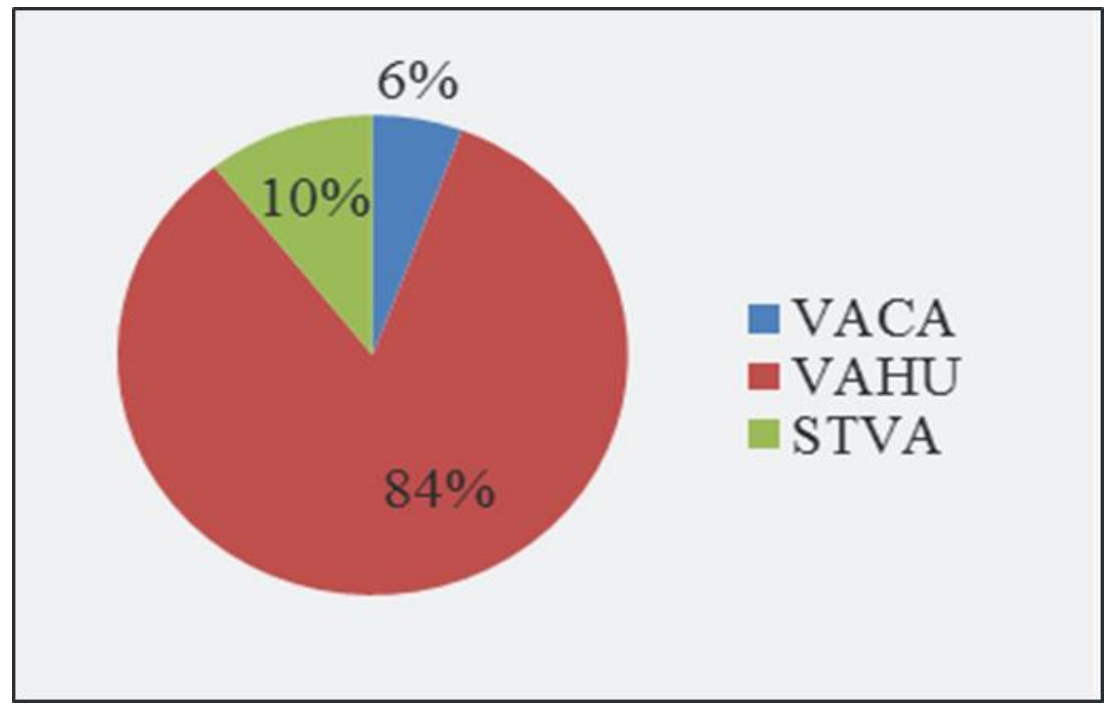

Sumber: Data diolah

Gambar 6 Komposisi komponen intellectual capital sub sektor asuransi

Berdasarkan perhitungan diatas, dari keempat sub sektor keuangan yang diamati, nilai VAHU atau human capital sangat mendominasi masing-masing sub sektor. VAHU merupakan indikator efisiensi nilai tambah modal manusia 
(human capital). Hubungan ini mengidentifikasi nilai bagi perusahaan dari dana yang dikeluarkan untuk tenaga kerja yang ada dalam perusahaan tersebut karena tenaga kerja merupakan entitas penciptaan nilai (value creating entity) (Fajarini, 2012). Semakin banyak value added yang dihasilkan dari setiap rupiah yang dikeluarkan perusahaan menunjukkan bahwa perusahaan telah mengelola sumber daya manusia dengan baik sehingga menghasilkan tenaga kerja berkualitas yang pada akhirnya akan meningkatkan kinerja keuangan perusahaan. Pramestiningrum (2013) menyatakan bahwa sumber daya manusia merupakan aset perusahaan yang dapat meningkatkan kualitas perusahaan dimana modal manusia ini mencerminkan kemampuan kolektif perusahaan untuk menghasilkan solusi terbaik berdasarkan pengetahuan yang dimiliki orang-orang dalam perusahaan tersebut.
Menurut Saryanti (2011), kinerja perusahaan merupakan suatu tampilan keadaan perusahaan selama periode tertentu. Kinerja perusahaan dapat diukur dari laporan keuangan yang dikeluarkan secara periodik yang memberikan suatu gambaran tentang posisi keuangan perusahaan. Kinerja perusahaan sangat esensial bagi manajemen karena menghasilkan outcome yang telah dicapai baik oleh individu atau kelompok individu dalam suatu organisasi yang terkait dengan otoritas dan tanggung jawab dalam mencapai legalitas tujuan, bukan terhadap hukum dan mengkonfirmasi moral dan etika. Kinerja merupakan fungsi kemampuan organisasi untuk mencapai dan mengatur sumber-sumber daya perusahaan dalam cara yang berbeda untuk mengembangkan keunggulan bersaing. Hasil perhitungan statistik komponen kinerja keuangan yang diamati dalam penelitian ini dapat dilihat pada Tabel 3.

Tabel 3 Hasil perhitungan statistik komponen kinerja keuangan

\begin{tabular}{lrrrrr}
\hline Variabel & $\mathrm{N}$ & Minimum & Maximum & Mean & Std. Deviation \\
\hline ROA_Bank & 150 & -.05677 & .03410 & .0129977 & .01125432 \\
ATO_Bank & 150 & .02282 & .16072 & .0642499 & .02850680 \\
GR_Bank & 120 & -.59509 & 244.236 & .1929310 & .42844825 \\
ROA_Financing & 55 & .00918 & .19316 & .0485464 & .02944809 \\
ATO_Financing & 55 & .06399 & .51281 & .2144184 & .08268041 \\
GR_Financing & 44 & -.76223 & .97089 & .1967143 & .29182741 \\
ROA_Effect & 50 & -.44136 & .20105 & .0160752 & .10667590 \\
ATO_Effect & 50 & -.33482 & .34735 & .1265336 & .10364484 \\
GR_Effect & 40 & -297.013 & 335.203 & .0154187 & .81087754 \\
ROA_Insurance & 50 & -.01338 & .11729 & .0578334 & .02931724 \\
ATO_Insurance & 50 & .10198 & .54408 & .2318752 & .11021658 \\
GR_Insurance & 40 & -.60852 & 218.326 & .3340005 & .49763048 \\
\hline SU
\end{tabular}

Sumber : data diolah

Ukuran kinerja keuangan perusahaan diwakili oleh ROA untuk proksi profitabilitas, ATO untuk proksi produktivitas, dan GR untuk ukuran pertumbuhan perusahaan. Berdasarkan hasil statistik dalam periode pengamatan 5 tahun, pada sub sektor perbankan dengan jumlah sampel yang diteliti 
adalah 150 sampel, rata-rata ROA adalah sebesar 0.0129977 dengan standar deviasi sebesar 0.01125432. Rata-rata ATO adalah sebesar 0.0642499 dengan standar deviasi 0.02850680. Rata-rata GR adalah sebesar 0.1929310 dengan standar deviasi 0.42844825. Pada sub sektor lembaga pembiayaan atau financing dengan dengan jumlah sampel yang diteliti adalah 55 sampel, rata-rata ROA adalah sebesar 0.0485464 dengan standar deviasi sebesar 0.02944809 . Rata-rata ATO adalah sebesar 0.2144184 dengan standar deviasi 0.08268041 . Rata-rata GR adalah sebesar 0.1967143 dengan standar deviasi 0.29182741 . Pada sub sektor perusahaan efek dengan dengan jumlah sampel yang diteliti adalah 50 sampel, rata-rata ROA adalah sebesar 0.0160752 dengan standar deviasi sebesar 0.10667590. Rata-rata ATO adalah sebesar 0.1265336 dengan standar deviasi 0.10364484. Rata-rata GR adalah sebesar 0.0154187 dengan standar deviasi 0.81087754. Pada sub sektor asuransi dengan dengan jumlah sampel yang diteliti adalah 50 sampel, rata-rata ROA adalah sebesar 0.0578334 dengan standar deviasi sebesar 0.02931724. Rata-rata ATO adalah sebesar 0.2318752 dengan standar deviasi 0.11021658. Rata-rata GR adalah sebesar 0.3340005 dengan standar deviasi 0.49763048 .

Profitabilitas merupakan salah satu dasar penilaian kondisi suatu perusahaan. Proksi profitabilitas yang diwakili oleh ROA menggambarkan kemampuan perusahaan untuk menghasilkan profit dengan menggunakan seluruh modal yang dimiliki perusahaan tersebut. Semakin besar nilai ROA perusahaan, maka semakin baik keadaan perusahaan tersebut. Profitabilitas suatu perusahaan akan mempengaruhi kebijakan para investor atas investasi yang dilakukan. Kemampuan perusahaan untuk menghasilkan laba dapat menarik investor untuk menanamkan dana dalam perusahaan tersebut, sebaliknya tingkat profitabilitas yang rendah akan menyebabkan investor menarik kembali dana mereka. Bagi manajemen perusahaan itu sendiri, profitabilitas dapat digunakan sebagai bahan evaluasi atas efektivitas pengelolaan perusahaan. Profitabilitas juga mempunyai arti penting dalam usaha mempertahankan kelangsungan perusahaan dalam jangka panjang, karena profitabilitas menunjukkan apakah perusahaan tersebut mempunyai prospek yang baik di masayang akan datang. Setiap perusahaan akan berusaha meningkatkan profitabilitas perusahaannya, karena semakin tinggi tingkat profitabilitas perusahaan, maka kelangsungan hidup perusahaan tersebut juga akan lebih terjamin.

Pada sub sektor perbankan, nilai ROA paling besar adalah Bank BRI (2013) sebesar 0.03410, dan nilai ROA paling kecil adalah Bank MNC Internasional Tbk (2014) sebesar 0.05677. Pada sub sektor financing, nilai ROA paling besar adalah Adira Dinamika Multi Finance Tbk (2010) sebesar 0.19316, dan nilai ROA paling kecil adalah HD Finance Tbk (2013) sebesar -0.00918. Pada sub sektor perusahaan efek, nilai ROA paling besar adalah Panin Sekuritas Tbk (2014) sebesar 0.20105 , dan nilai ROA paling kecil adalah Majapahit Securities Tbk (2011) sebesar -0.44136. Pada sub sektor asuransi, nilai ROA paling besar adalah Maskapai Reasuransi Indonesia Tbk (2012) sebesar 0.11729, dan nilai ROA paling kecil adalah Asuransi Bintang Tbk (2011) sebesar -0.01338 .

Pengukuran produktivitas merupakan suatu alat manajemen yang penting di semua tingkatan ekonomi. Pengukuran produktivitas berhubungan dengan perubahan produktivitas 
sehingga usaha-usaha untuk meningkatkan produktivitas dapat dievaluasi. Pengukuran produktivitas ini untuk melihat apakah efisiensi produktif suatu perusahaan meningkat atau tidak. Hal ini sebagai informasi untuk menyusun strategi bersaing dengan perusahaan pesaing, karena perusahaan yang produktivitasnya rendah biasanya kurang dapat bersaing dengan perusahaan yang produktivitasnya tinggi. Proksi produktivitas diwakili oleh ATO menggambarkan perbandingan antara output yang dihasilkan dari kegiatan operasional perusahaan dengan keseluruhan sumber daya yang digunakan, seperti tenaga kerja, bahan baku, modal dan energi (input) oleh perusahaan tersebut. Semakin tinggi nilai produktivitas perusahaan, maka semakin efisien pengelolaan sumber daya perusahaan maka output atau hasil yang didapat oleh perusahaan semakin baik.

Pada sub sektor perbankan, nilai ATO paling besar adalah Bank Swadesi Tbk (2010) sebesar 0,16072, dan nilai ATO paling kecil adalah Bank Victoria Internasional Tbk (2014) sebesar 0,02282 . Pada sub sektor financing, nilai ATO paling besar adalah Adira Dinamika Multi Finance Tbk (2010) sebesar 0,51281, dan nilai ATO paling kecil adalah Danasupra Erapacific Tbk (2010) sebesar 0,06399. Pada sub sektor perusahaan efek, nilai ATO paling besar adalah Panin Sekuritas Tbk (2014) sebesar 0,34735, dan nilai ATO paling kecil adalah Majapahit Sekuritas Tbk (2011) sebesar -0,33482. Pada sub sektor asuransi, nilai ATO paling besar adalah Asuransi Bina Dana Arta Tbk (2012) sebesar 0,54408, dan nilai ATO paling kecil adalah Lippo General Insurance Tbk (2013) sebesar 0,10198.

Pengukuran nilai profitabilitas dan produktivitas perusahaan ditujukan untuk melihat performa suatu perusahaan. Performa suatu perusahaan juga tidak lepas dari peran modal intelektual sebagai sumber daya yang ada di dalam perusahaan tersebut. Dengan berbasis pada penelitian Kamath (2007) mengenai modal intelektual dan kinerja perusahaan dalam hal performa perusahaan, maka dilakukan juga penilaian performa modal intelektual perusahaan-perusahaan sektor keuangan yang terdaftar di BEI 2010-2014. Penilaian BPI (Business Performance Indicator) perusahaan sektor keuangan dapat dilihat pada Tabel 4. 
Tabel 4 Busines performance indicator sektor keuangan

\begin{tabular}{llrrrrr}
\hline Sub Sektor & BPI & 2010 & 2011 & 2012 & 2013 & 2014 \\
\hline Perbankan & Top Performers & 9 & 12 & 9 & 11 & 8 \\
& Good Performers & 3 & 1 & 3 & 2 & 3 \\
& Common Performers & 9 & 9 & 14 & 11 & 9 \\
& Bad Performers & 9 & 8 & 4 & 6 & 10 \\
& Total & 30 & 30 & 30 & 30 & 30 \\
Financing & Top Performers & 4 & 6 & 5 & 2 & 1 \\
& Good Performers & 1 & 1 & 2 & 1 & 1 \\
& Common Performers & 3 & 4 & 4 & 6 & 6 \\
Perusahaan & Bad Performers & 2 & 0 & 0 & 2 & 3 \\
& Total & 11 & 11 & 11 & 11 & 11 \\
& Top Performers & 4 & 2 & 3 & 3 & 1 \\
& Good Performers & 1 & 1 & 1 & 0 & 3 \\
& Common Performers & 1 & 2 & 0 & 1 & 1 \\
& Bad Performers & 4 & 5 & 6 & 6 & 5 \\
Asuransi & Total & 10 & 10 & 10 & 10 & 10 \\
& Top Performers & 5 & 4 & 4 & 5 & 5 \\
& Good Performers & 0 & 1 & 0 & 1 & 0 \\
& Common Performers & 3 & 3 & 4 & 1 & 3 \\
& Bad Performers & 2 & 2 & 2 & 3 & 2 \\
& Total & 10 & 10 & 10 & 10 & 10 \\
\hline
\end{tabular}

Kamath (2007) mengelompok-kan performa perusahaan berdasarkan intellectual capital ke dalam empat kategori, yaitu top performers, good performers, common performers, dan bad performers. Perbedaan keempat kategori performa perusahaan ini didasarkan pada nilai VAIC perusahaan tersebut, antara lain:

1. Top Performers : untuk perusahaan dengan nilai VAIC di atas 5

2. Good performers : untuk perusahaan dengan nilai VAIC antara 4 - 5

3. Common Performers : untuk perusahaan dengan nilai VAIC antara $2,5-4$

4. Bad Performers : untuk perusahaan dengan nilai VAIC dibawah 2,5

Dari Tabel 4 dapat dilihat sebaran kategori BPI perusahaan sektor keuangan setiap tahunnya dimana mayoritas perusahaan-perusahaan sektor keuangan adalah top performers dan common performers. Meski jumlah perusahaan yang ada dalam kategori BPI fluktuatif, namun dapat dilihat bahwa mayoritas perusahaan-perusahaan yang ada dalam sub sektor perbankan, sub sektor lembaga pembiayaan, dan sub sektor asuransi berada pada kategori top performers dan common performers. Hal ini menggambarkan mayoritas perusahaan-perusahaan di sektor keuangan, terutama sub sektor perbankan, sub sektor lembaga pembiayaan, dan sub sektor asuransi menunjukkan performa yang cenderung baik. Pada sub sektor perusahaan efek, nilai BPI menunjukkan mayoritas perusahan yang ada dalam sub sektor tersebut setiap tahunnya masuk ke dalam kategori bad performers dimana nilai BPI yang dimiliki perusahaan yang masuk kedalam kategori bad performers 
adalah di bawah 2,5. Hal ini menunjukkan bahwa mayoritas perusahaan yang ada dalam sub sektor perusahaan efek masih belum mengelolah sumber daya yang dimilikinya dengan baik, terutama modal intelektual.

Nilai BPI masing-masing perusahaan setiap tahunnya mengalami fluktuasi. Hal ini menunjukkan bahwa performa perusahaan setiap tahunnya tidak stabil. Ketidakstabilan tersebut kemungkinan diakibatkan oleh adanya krisis dan isu-isu ekonomi lainnyasehingga pengelolaan sumber daya pada perusahaan-perusahaan sektor keuangan menjadi tidak maksimal dan berdampak pada performa perusahaanperusahaan itu sendiri. Nilai BPI sektor keuangan yang mengalami fluktuasi dapat dilihat pada Gambar 6 .

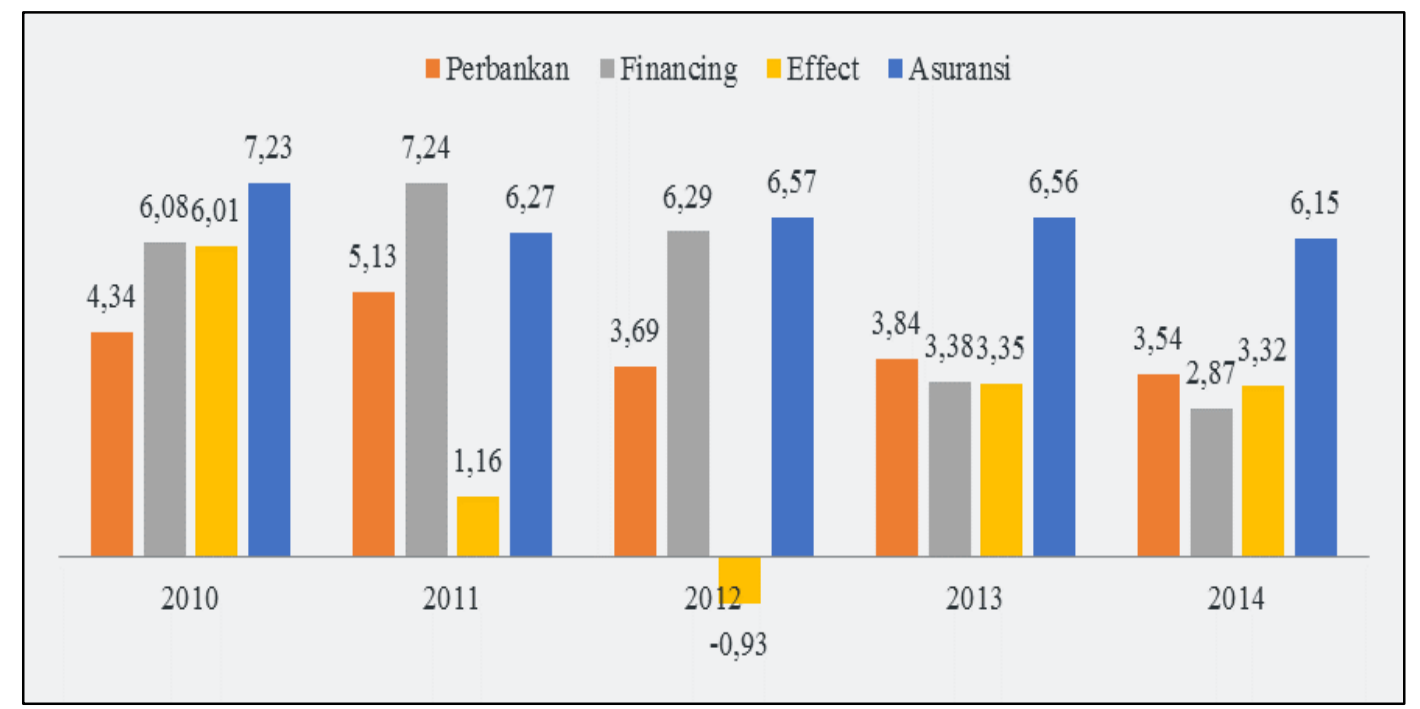

Sumber: Data diolah

Gambar 6. Rata-rata nilai BPI sektor keuangan

Dari gambar tersebut rata-rata nilai BPI sub sektor perbankan pada tahun 2010 adalah 4,34 kemudian menglami peningkatan menjadi 5,13. pada tahun 2013, nilai BPI sub sektor perbankan mengalami penurunan menjadi 3,69, selanjutnya mengalami peningkatan menjadi 3,84 pada 2013 , dan mengalami penurunan kembali pada 2014 menjadi 3,54. Berdasarkan nilai rata-rata BPI tersebut, sub sektor perbankan berada pada kategori common performers dengan nilai rata-rata BPI diantara 2,5 sampai 4.

Rata-rata nilai BPI sub sektor lembaga pembiayaan tahun 2010 adalah 6,08 kemudian mengalami peningkatan tahun berikutnya menjadi 7,24. Pada 2012, nilai rata-rata BPI sub sektor lembaga pembiayaan mengalami penurunan menjadi 6,29 , dan terus mengalami penurunan pada tahun-tahun berikutnya menjadi 3,38 dan 2,87. Berdasarkan nilai rata-rata BPI tersebut sub sektor lembaga pembiayaan berada pada kategori top performers, namun 2 tahun terakhir, yaitu 2013 dan 2014 mengalami penurunan drastis hingga berada pada kategori common performers.

Nilai rata-rata BPI sub sektor perusahaan efek tahun 2010 sebesar 6,01 dan mengalami penurunana drastis dua tahun berikutnya menjadi 1,16 dan $-0,93$. kemudian pada 2013 mengalami peningkatan kembali menjadi 3,35 dan tahun 2014 menjadi 3,32. Sub sektor perusahaan efek mengalami fluktuasi 
yang sangat signifikan, yang awalnya pada 2010 berada pada kategori top performers, kemudian mengalami penurunan drastis menjadi kategori bad performers. Tahun berikutnya, sub sektor perusahaan efek mulai memperbaiki performanya sehingga berhasil berada pada kategoricommon performers.

Rata-rata nilai BPI sub sektor asuransi juga mengalami fluktuasi sama seperti ketiga sub sektor lainnya. Pada 2010, sub sektor perusahaan asuransi memiliki nilai rata-rata BPI sebesar 7,23 kemudian mengalami penurunan menjadi 6,27. Tahun berikutnya nilai rata-rata BPI sub sektor asuransi mengalami peningkatan menjadi 6,57 dan berhasil mempertahankan nilai tersebut pada tahun berikutnya, namun pada 2014, nilai rata-rata BPI sub sektor asuransi mengalami penurunan menjadi 6,15. Meski mengalami fluktuasi, namun sub sektor perusahaan asuransi tetap berada pada kategori top performers dari tahun 2010 hingga 2014. Hasil rata-rata nilai BPI sub sektor perbankan yang fluktuatif ini disebabkan fluktuatifnya komponen modal intelektual, seperti human capital, structural capital, dan customer capital yang ada dalam perusahaan.

\section{KESIMPULAN}

Sektor keuangan sebagai salah satu penunjang perekonomian negara memiliki peran penting dalam meningkatkan pertumbuhan perekonomian. Perusahaan-perusahaan di sektor keuangan berperan penting sebagai media investasi dan penyedia dana pembiayaan perekenomian. Semakin baik keadaan sektor keuangan, maka semakin meningkat penyediaan dana bagi pembiayaan perekonomian sehingga terjadi pertumbuhan ekonomi. Baik atau tidaknya sektor keuangan tidak terlepas dari peran masing-masing sub sektor, yaitu perbankan, lembaga pembiayaan, perusahaan efek, dan asuransi. Sub sektor perbankan memiliki kontribusi yang besar dalam sektor keuangan dimana sebanyak $53 \%$ emiten yang ada pada sektor keuanagan merupakan perbankan.

Kontribusi perusahaan-perusahaan sektor keuangan tidak terlepas dari pengelolaan sumber daya yang dimiliki perusahaan dengan baik. Salah satu sumber daya yang perlu dimaksimalkan adalah modal intelektual. Modal intelektual merupakan aset perusahaan yang dapat memberikan keunggulan kompetitif bagi perusahaan apabila dapat dikelolah dengan baik. Pengelolaan modal intelektual yang baik dapat memberikan nilai tambah yang unik dan sulit ditiru oleh pesaing. Perusahaan yang memiliki keunggulan kompetitif akan dapat bertahan dalam menghadapi perubahan pasar. Hasil analisis mengenai modal intelektual pada perusahaan sektor keuangan menunjukkan bahwa komponen modal intelektual yang mendominasi adalah human capital. Dari empat sub sektor keuangan yang diteliti, semua sub sektor menunjukkan hasil yang sama, bahwa variabel VAHU atau human capital merupakan komponen modal intelektual yang berkontribusi paling besar. Hal ini membuktikan bahwa kualitas sumber daya manusia yang ada pada perusahaan merupakan hal penting yang dapat memberikan keunggulan kompetitif bagi perusahaan.

Keberadaan sumber daya manusia yang memiliki keterampilan dan kompetensi tinggi merupakan keunggulan kompetitif bagi perusahaan apabila potensi yang dimiliki sumber daya manusia tersebut dapat diolah dengan baik. Pengelolaan human capital yang baik berakibat pada meningkatnya produktivitas karyawan atau sumber daya manusia. Dengan adanya 
peningkatan produktivitas, maka kinerja perusahaan akan meningkat dan dengan adanya pengelolaan sumber daya yang efektif tersebut maka pemakaian sumber daya atau pengeluaran akan lebih efektif dan efisien. Berdasarkan hasil identifikasi Business Performance Indicator pada perusahaan-perusahaan sektor keuangan, menunjukkan bahwa mayoritas perusahaan-perusahaan yang ada dalam sub sektor perbankan, sub sektor lembaga pembiayaan, dan sub sektor asuransi berada pada kategori top performers dan common performers. Hal ini menggambarkan mayoritas perusahaan-perusahaan di sektor keuangan, terutama sub sektor perbankan, sub sektor lembaga pembiayaan, dan sub sektor asuransi menunjukkan performa yang cenderung baik.

\section{DAFTAR PUSTAKA}

Abidin. 2000. Pelaporan MI : Upaya Mengembangkan Ukuran-Ukuran Baru. Jurnal Media Akuntansi. 7 (8): 46-47.

Appuhami, BA. Ranjith. 2007. The Impact of Intellectual Capital on Investor Capital Gains on Share: An Empirical Investigation of Thai Banking, Finance and Insurance Sector. Journal of International Management Review. 2 (2): 81-95.

Chen MC, Cheng SJ, Hwang Y. 2005. An Empirical Investigation of The Relationship Between Intellectual Capital and Firms' Market Value and Financial Performance. Journal of Intellectual Capital. 6 (2): 159-176.

Deegan C. 2004. Financial Accounting Theory. Sydney: McGraw-Hill Book Company.

Fajarini I, Firmansyah R. 2012. Pengaruh Intellectual Capital Terhadap Kinerja Keuangan Perusahaan
(Studi Empiris Perusahaan LQ 45). Jurnal Dinamika Akuntansi. 4 (1): 1-12.

Firer S, Williams SM. 2003. Intellectual Capital and Traditional Measures of Corporate Performance. Journal of Intellectual Capital. 4 (3): 348360.

Ghozali, I. 2011. Aplikasi Analisis Multivariate dengan Program IBM: SPSS 19. Semarang (ID): Lembaga Penerbit Universitas Diponegoro.

Gitman LJ, Chad JZ. 2012. Principles of Managerial Finance. England: Pubisher Pearson.

Hariyawan, A. 2013. Pengaruh Intellectual Capital Terhadap Kinerja Keuangan Perusahaan Perbankan yang Terdaftar di BEI periode 2007-2011 [tesis]. Yogyakarta (ID): Program Pascasarjana, Universitas Gadjah Mada.

Kamath GB. 2007. The Intellectual Capital Performance of Indian Banking Sector. Journal of Intellectual Capital. 8 (1): 96-123.

Kaminsky GL. 1999. The Twin Crises: The Cause of Banking and Balance of Payments Problems. Journal of American Economic Review. 89 (3): 473-500.

Kularatne C. 2002. An Examination of the Impact of Financial Deepening on Long-Run Economic Growth : An Application of a VECM Structure to a Middle-Income Country Context [Internet]. [Diunduh 2015 September 10]. Tersedia pada :http://www.csae.ox.ac.uk.

Lee J. 2005. Financial Intermediation and Economic Growth Evidence from Canada. Journal of Economic Literature. 35 (2): 688-726.

Pramelasari, YM. 2010. Pengaruh Intellectual Capital Terhadap 
Nilai Pasar dan Kinerja Keuangan Perusahaan. Semarang (ID): Lembaga Penerbit Universitas Diponegoro.

Pramestiningrum. 2013. Pengaruh Intellectual Capital Terhadap Kinerja Perusahaan Sektor Keuangan yang Terdaft1; ar di BEI taun 2009-2011. [tesis] Semarang (ID) : Program Pascasarjana, Universitas Diponegoro.

Pulic, A. 1998. Measuring the performance of intellectual potential in the knowledge econom. Paper from the Austrian Intellectual Capital Research Centre.

Purnomosidhi, B. 2006. Praktik Pengungkapan Modal Intelektual pada Perusahaan Publik di BEJ. Jurnal Riset Akuntansi Indonesia. 9 (1): 1-20.

[OECD] Organization for Economic Cooperation and Development.
1999. International Symposium on Measuring and Reporting Intellectual Capital:Experience, Issues and Prospects. Amsterdam Working Paper 9.

Sangkala. 2006. Intellectual Capital Management: Strategi Baru Membangun Daya Saing Perusahaan. Jakarta (ID): Yapensi.

Santoso W. 2008. Outlook Ekonomi Indonesia 2008-2012: Integrasi ekonomi ASEAN dan prospek perekonomian nasional. Jakarta (ID): Biro Riset Ekonomi Direktorat Riset Ekonomi dan Kebijakan Moneter.

Saryanti, E. 2011. Pengaruh Intellectual Capital Terhadap Kinerja Keuangan Perusahaan Perbankan yang Terdaftar di BEI Tahun 20072009. Jurnal Ekonomi Bisnis dan Perbankan STIE AUB Surakarta. 5(1): 31-51. 